УДК 621.318.38:631.53.027.3

(C) 2016

\author{
Кузнецова Т. Ю., кандидат хімічних наук, \\ Ківа О. В., старший викладач, \\ Грибініченко В. В., студент
}

Полтавський національний технічний університет імені Юрія Кондратюка

\title{
ДОСЛІДЖЕННЯ УЛЬТРАЗВУКОВОГО СПОСОБУ НАНЕСЕННЯ ЕМІТЕРА НА ЕЛЕКТРОДИ ГАЗОРОЗРЯДНИХ ЛАМП
}

\section{Рецензент - доктор технічних наук О. В. Нижник}

Була проведена розробка способу нанесення емітера на електроди газорозрядних ламп, який відрізняється тим, щзо до та під час занурення $і$ витримки електродів у суспензї остання опромінюється ультразвуком, який вимикається перед тим, як електроди виймають із суспензіі. Проведені експериментальні дослідження на електродах ламп ДРЛ-250 із вивчення впливу ультразвуку на приріст маси емітера, нанесеного на електрод, і на ступінь заповнення внутрішніх порожнин електрода емітером, на основі яких запропонована технологія ультразвукового нанесення емітера на електроди газорозрядних ламп. Подаються результати проведених експериментальних випробувань та одержані порівняльні характеристики для способів нанесення емітера на електроди газорозрядних ламп за відомою технологією та з використанням ультразвуку.

Ключові слова: газорозрядні лампи, емітер, електрод, суспензія, ультразвук.

Постановка проблеми. Термін служби газорозрядних ламп визначається якістю нанесення емітера на їх електроди, яка залежить, у свою чергу, від рівномірності нанесення шару емітера та наповненості внутрішніх порожнин електрода емітером [1].

Аналіз останніх досліджень і публікацій, у яких започатковано розв'язання проблеми. Відомий спосіб нанесення емітера полягає в зануренні електродів у рідину, в якій суспензують емітер, витримці у ній та подальшому випаровуванні розчинника [4]. Цей спосіб, на жаль, не забезпечує якісного заповнення порожнин, утворених витками спіралі та керном. Частково ця проблема вирішена нанесенням емітера на електроди газорозрядних ламп шляхом вакуумування [3]. Спосіб полягає в тому, що електроди завантажують у герметичну посудину, відкачують із неї повітря, після чого в посудину під тиском подають суспензію емітера, в якій витримують електроди. Після витримки суспензію зливають, електроди виймають і випаровують розчинник. Проте вказаний спосіб технологічно складний - супроводжується значними втратами дорогої суспензії в трубопроводах технологічного устаткування.

Мета - дослідити ультразвуковий спосіб нанесення емітера на електроди газорозрядних ламп для збільшення маси емітера, покращання технологічності процесу та зменшення втрат емітера.

Завдання дослідження. На думку авторів, ультразвукове опромінювання покращить заповнення порожнин електрода суспензію за рахунок зміни іiі фізичних характеристик, таких як густина та в'язкість, та зменшить швидкість осідання емітера в суспензії, що сприятиме зменшенню варіацій маси емітера на окремих електродах.

Методи дослідження. Випробування проводилися із використанням суспензії порошків цирконату барію та окису ітрію у воді на електродах ртутних дугових ламп високого тиску ДРЛ-250, які являють собою центральний стрижень - керн iз вольфраму діаметром 1 мм, із накрученою на нього двошаровою спіраллю 3 вольфрамового дроту діаметром 0,4 мм, 3 числом витків у першому шарі $11 \pm 1$, у другому шарі $-8 \pm 1$. Під час застосування відомого способу нанесення еміте$\mathrm{pa}$, який полягає в тому, що електрод занурюють та витримують у рідкій суспензії емітера, а потім виймають і випаровують розчинник. До занурення, під час занурення та витримки електродів у суспензії, остання опромінюється ультразвуком, який вимикається перед тим, як електроди виймають із суспензії.

Результати досліджень. Практичне здійснення такого процесу полягає у тому, що в посудину 3 розташованим у ній випромінювачем ультразвуку наливають суспензію емітера та вмикають генератор ультразвуку.

Електроди вміщують у сітчастий кошик, який опускають в посудину зі суспензією емітера. Після витримки електродів у суспензії ультразвуковий генератор вимикають, кошик з електродами виймають та поміщують в сушильну шафу, в якій випаровують розчинник. 


\begin{tabular}{|c|c|c|c|}
\hline Середня маса електрода (мг) & $\begin{array}{c}\text { Відомий } \\
\text { спосіб }\end{array}$ & $\begin{array}{c}\text { Ультразвуковий } \\
\text { спосіб }\end{array}$ & \multirow{4}{*}{$\begin{array}{c}\text { Приріст маси } \\
\text { емітера } \\
\text { порівняно з } \\
\text { відомим } \\
\text { методом. } \\
\text { Приріст маси } \\
\text { емітера }\end{array}$} \\
\hline До нанесення емітера & 440,8925 & 440,2824 & \\
\hline Після сушіння & 445,6975 & 446,4996 & \\
\hline Після очищення емітера, що обсипався & 442,1513 & 442,0494 & \\
\hline \multicolumn{3}{|c|}{ Середня маса емітера, нанесеного на електрод (мг) } & \\
\hline Після сушіння & 4,8050 & 6,2172 & $29,4 \%$ \\
\hline Після очищення емітера, який обсипався & 1,2588 & 1,7670 & $40,4 \%$ \\
\hline
\end{tabular}

Для порівняння з відомою технологією паралельно нанесли емітер на іншу партію електродів без застосування ультразвуку [2]. В обох партіях (по 119 шт.) визначили масу електродів без емітера і з емітером одразу після сушіння. Після зважування електроди 3 емітером, нанесеним за обома методами, помістили в пробірки й усю партію потрусили, потім висипали в плоскі кювети і продули стисненим повітрям для видалення емітера, що обсипався 3 електродів, і зважили кожну партію знову.

Результати випробувань наведені у таблиці.

Із даних таблиці бачимо, що запропонований авторами спосіб дає змогу збільшити масу нанесеного на електрод емітера, що підвищить ресурс дугових ртутних ламп [5], водночас зростання маси нанесеного емітера відбувається за рахунок щільнішого заповнення внутрішніх порожнин електродів, що забезпечує не тільки більш надійне з'єднання емітера 3 електродом. Необхідно вказати на суттєвий вплив густини суспензії на масу емітера. Використання суспензії з великою густиною збільшує масу за рахунок

\section{БІБЛІОГРАФІЯ}

1. Герус В. Л. Физические основы электроннолучевых приборов / В. Л. Герус. - М. : Наука, 1993. - $228 \mathrm{c}$.

2. Денисов В. П. Производство электрических источников света / В. П. Денисов. - М. : Наука, 1975. - $488 \mathrm{c}$.

3. Ківа О. В. Розробка способу нанесення емітера на електроди газорозрядних ламп 3 шляхом вакуумування / О. В. Ківа, Є. В. Китаєв, В. Є. Ходурський // Вісник Полтавської державної аграр- емітера, розташованого на зовнішніх поверхнях електродів, але помітно зменшує кількість емітера в порожнинах електродів. Окрім того, ультразвукове опромінення зменшує швидкість осідання емітера в суспензії, що сприятиме зменшенню варіацій маси емітера на окремих електродах.

Проста геометрія ємності та уповільнення осідання емітера в суспензії забезпечує зменшення технологічних втрат емітера.

Висновок. Запропонований спосіб дає змогу збільшити масу емітера на електродах, скорочує розсіювання значень маси емітера, викликане коливаннями густини суспензії, дає можливість наносити емітер на відносно великі партії електродів одночасно, що в декілька разів збільшує продуктивність праці на цій технологічній операції. Застосування запропонованого способу практично не збільшує трудоємності процесу, не потребує складного обладнання [2], у зв'язку із чим він може бути реалізованим без суттєвих затрат в існуючому технологічному процесі виготовлення електродів газорозрядних ламп.

ної академії. - №3. - Полтава : РВВ ПДАА, 2014. C. $183-184$.

4. Патент UA№7903, МПК 7Н01J9/02. Спосіб нанесення емітера на електроди газорозрядних ламп / Ходурський В. С., Фернебок О. - Бюл. ДДІВ України №7, 2005.

5. Рохлин Г.Н. Разрядные источники света / Г. Н. Рохлин. - М. : Энергоатомиздат, 1991. $416 \mathrm{c}$. 